\title{
Research on environmental Accounting Information Disclosure of energy Pollution Industry -- Case of the listed companies in coal industry
}

\author{
Hong $\mathrm{Li}^{1}$ \\ ${ }^{1}$ Shandong Women's University, China
}

\begin{abstract}
The coal industry plays a pivotal role in China's energy industry, which not only brings about rapid economic growth but also causes serious ecological environmental problems. This paper selects 25 listed companies in the coal mining and washing industry as the research objects to analyse the current situation and problems of environmental accounting information disclosure. This paper puts forward some suggestions for improving the environmental disclosure, so as to provide reference for promoting the transformation and upgrading of the coal industry.
\end{abstract}

\section{The introduction}

The report to the 19th National Congress of the CPC stated that green development is an important demand for building a high-quality modern economic system. The development of the energy industry should actively implement the spirit of the report of the 19th National Congress and promote the construction of a clean and lowcarbon energy system. In 2019, raw coal production accounted for 69.6 percent of China's total one-time energy production, while coal consumption accounted for 57.7 percent of total energy consumption. It can be seen that the current coal industry occupies a major position in the entire energy industry. The coal industry has made outstanding contributions to the economic growth but also brought huge environmental pressure to the society. For example, the coal mining process will lead to the destruction of land resources, plant resources, air pollution and water pollution and other problems. Therefore, the disclosure of environmental accounting information about the coal industry has become the focus of scholars and the community.

\section{Current situation of environmental accounting information disclosure of listed companies in the coal industry}

\subsection{Sample selection of environmental accounting information disclosure of listed companies in coal industry}

According to the industry classification results of listed companies by China Securities Regulatory Commission in the first quarter of 2019, the coal mining and washing industry contains a total of 27 listed companies. After excluding the B-share listed Yintai B shares and *ST companies, this paper uses the remaining 25 listed companies as the research samples. This paper mainly analyzes the basic situation of environmental accounting information disclosure based on the sample companies' 2019 annual report, social responsibility report and the environmental accounting information disclosed in the prospectus. The basic information of sample companies is shown in Table 1.

Table1. Sample company basic information table.

\begin{tabular}{|c|c|c|c|}
\hline Stock code & $\begin{array}{l}\text { The } \\
\text { company } \\
\text { referred to } \\
\text { as" }\end{array}$ & Stock code & $\begin{array}{l}\text { The company } \\
\text { referred to as" }\end{array}$ \\
\hline 000552 & $\begin{array}{l}\text { Jing yuan } \\
\text { coal }\end{array}$ & 600714 & Jinrui mining \\
\hline 000780 & $\begin{array}{l}\text { PingZhuang } \\
\text { energy }\end{array}$ & 600758 & $\begin{array}{c}\text { Hongyang } \\
\text { energy }\end{array}$ \\
\hline 000937 & $\begin{array}{l}\text { Hebei } \\
\text { central } \\
\text { energy }\end{array}$ & 600971 & Turbine coal \\
\hline 000983 & $\begin{array}{l}\text { Xishan coal } \\
\text { and } \\
\text { electricity }\end{array}$ & 600985 & $\begin{array}{l}\text { Huaibei } \\
\text { mining }\end{array}$ \\
\hline 002128 & $\begin{array}{l}\text { Open-air } \\
\text { coal }\end{array}$ & 601001 & Datong coal \\
\hline 600121 & $\begin{array}{l}\text { Zhengzhou } \\
\text { coal }\end{array}$ & 601088 & $\begin{array}{l}\text { China } \\
\text { shenhua } \\
\text { energy }\end{array}$ \\
\hline 600123 & $\begin{array}{c}\text { Orchid } \\
\text { kechuang }\end{array}$ & 601101 & $\begin{array}{c}\text { HaoHua } \\
\text { energy }\end{array}$ \\
\hline 600157 & $\begin{array}{l}\text { Yongtai } \\
\text { energy }\end{array}$ & 601225 & Shanxi coal \\
\hline 600188 & $\begin{array}{c}\text { Yanzhou } \\
\text { Coal }\end{array}$ & 601666 & Ping Coal \\
\hline
\end{tabular}




\begin{tabular}{|c|c|c|c|}
\hline 600348 & $\begin{array}{c}\text { Yangquan } \\
\text { coal }\end{array}$ & 601699 & $\begin{array}{c}\text { LuAn ring } \\
\text { can }\end{array}$ \\
\hline 600395 & $\begin{array}{c}\text { Panjiang } \\
\text { shares }\end{array}$ & 601898 & $\begin{array}{c}\text { China coal } \\
\text { energy }\end{array}$ \\
\hline 600403 & $\begin{array}{c}\text { Great } \\
\text { energy }\end{array}$ & 601918 & Xinji energy \\
\hline 600508 & $\begin{array}{c}\text { Shanghai } \\
\text { energy }\end{array}$ & & \\
\hline
\end{tabular}

2.2 The disclosure of environmental accounting Information of listed companies in the coal industry

\subsubsection{The form distribution of environmental accounting information disclosure of listed companies in coal industry}

Environmental accounting information of listed companies in China's coal industry is mainly disclosed in the form of prospectus, annual report and social responsibility report. The detailed information disclosure form and distribution of environmental accounting information of listed companies in the coal industry in 2019 are shown in Table 2.

Table2. The distribution of environmental accounting information disclosure of listed companies in the coal industry in 2019.

\begin{tabular}{|c|c|c|}
\hline Disclosure forms & $\begin{array}{c}\text { Number of } \\
\text { Disclosures } \\
\text { (pieces) }\end{array}$ & The proportion \\
\hline Prospectus & 15 & $60 \%$ \\
\hline $\begin{array}{c}\text { The annual } \\
\text { report }\end{array}$ & 25 & $100 \%$ \\
\hline $\begin{array}{c}\text { Social } \\
\text { responsibility } \\
\text { report }\end{array}$ & 13 & $52 \%$ \\
\hline
\end{tabular}

Through the investigation of the 25 sample companies mentioned above, it is found that the most common form of environmental accounting information disclosure of listed companies in China's coal industry is the annual report, and the 25 sample companies all made relevant disclosures in the 2019 annual report. The disclosure content is mainly distributed in the environmental information part of the notes. The specific content mainly includes information on the company's pollution discharge fee, environmental protection investment, solid waste, and safe disposal rate of hazardous waste. In addition, prospectus and social responsibility report are also the environmental accounting information disclosure forms that sample companies often choose. 15 companies disclosed environmental accounting information through the prospectus, and the sample number accounts for $60 \%$ of the total sample companies. The environmental accounting information in the prospectus is mainly distributed in the part that restricts environmental factors. The 13 sample companies released their social responsibility reports for 2019 and explained environmental accounting information.

\subsubsection{The contents of environmental accounting information disclosure of listed companies in coal industry}

The emphasis of environmental accounting information disclosed by different disclosure forms is different. This part summarizes and analyzes the characteristics of environmental accounting information disclosed in the three forms.

2.2.2.1 Environmental accounting information disclosed in the annual report

The content of environmental accounting information disclosed in the annual report is mainly distributed in chapters such as business discussion and analysis, important matters and notes to financial reports. The discussion and analysis part of the business situation mainly explains the impact of environmental governance on the amount of long-term receivables and estimated liabilities for the current period, and briefly explains the environmental protection tax payment, environmental protection facility investment and environmental governance. The important matters section mainly explains the pollution discharge information, the degree of environmental impact of construction projects, and the emergency plan for emergencies. The environmental accounting information disclosed in the notes to the financial statements mainly includes reclamation, disposal and environmental cleaning expenses, sewage discharge fees, environmental governance security deposit, investment in the acquisition of special equipment for environmental protection, environmental protection subsidies, environmental protection taxes, resource taxes and other contents. In general, the sample companies' 2019 annual report disclosed less about environmental assets, and mainly focused on environmental deposits. The disclosure level of environmental expenses and environmental liabilities is the highest. The disclosure of environmental benefits is mainly manifested in subsidies. 2.2.2.2 Environmental accounting information disclosed in the prospectus

The prospectus is an important basis for shareholders to purchase enterprise stocks. For listed companies engaged in coal mining and washing industry, it is necessary to properly explain the environmental information in the prospectus. The contents disclosed in the prospectus mainly include the environmental pollution problems that the company will bring, pollution treatment methods, and environmental governance cost estimates. In general, the disclosure of environmental accounting information in the prospectus is mainly written description and lacks certain quantitative indicators.

2.2.2.3 Environmental accounting information disclosed in social responsibility reports

The disclosure of environmental accounting information in the social responsibility report mainly involves pollution reduction and emission reduction, ecological protection, resource conservation and other aspects. But generally speaking, the content of environmental accounting information disclosure in social responsibility reports is mostly qualitative description, but less quantitative description. 


\section{Problems existing in environmental accounting information disclosure of listed companies in coal industry}

\subsection{Disclosure comes in many forms but lacks uniformity}

China has not unified regulations on the form of environmental accounting information disclosure of listed companies in the coal industry. Listed companies in the coal industry can choose to disclose in various forms such as annual reports, prospectuses and social responsibility reports. The lack of uniformity in the form of information disclosure, on the one hand, reduces the efficiency of information users in collecting information, on the other hand, the overlapping of multiple disclosure methods also leads to an increase in corporate disclosure costs. In addition, the lack of uniform forms and standards also leads to the lack of comparability in environmental accounting information disclosure of the same enterprise in different periods, and the lack of comparability in environmental accounting information disclosure between different enterprises.

\subsection{The content of information disclosure lacks comprehensiveness}

China does not have strict regulations on the content of environmental accounting information disclosure, which is the enterprise's independent choice, subjective and arbitrary, lack of comprehensiveness and consistency. Listed companies in the coal industry tend to disclose projects and indicators that are conducive to the development of enterprises, such as the amount of government subsidies, environmental governance margin, etc., while less disclosure of adverse projects, such as the payment of fines. Moreover, the environmental accounting information disclosed by enterprises is mostly qualitative information description, while the monetary measurement of environmental accounting indicators is less.

\subsection{The quality of information disclosure needs to be improved}

Environmental accounting information should not only reflect the actual situation of enterprises in a real and objective way, but also possess the characteristics of information quality such as comprehensibility, substance over form and comparability. However, China's current accounting standards have not established a complete and unified disclosure standard for environmental accounting information disclosure. There are certain differences in the recognition and measurement of environmental accounting information of listed companies in the coal industry, and the comparability of enterprises in the same industry is poor. The environmental accounting information provided by the company cannot meet the decision-making needs of information users.

\section{Suggestions on improving the environmental accounting information disclosure of listed companies in the coal industry}

\subsection{Improve the environmental accounting information disclosure system of listed companies in the coal industry}

With the promotion of the concept of green development, listed companies in the coal industry have become more aware of environmental accounting information disclosure. However, due to the lack of environmental accounting information disclosure standards and systems, coal companies' environmental accounting information disclosure methods are not standardized. Therefore, it is recommended that the national financial department and other institutions gradually standardize the standards for environmental accounting information disclosure in the coal industry, and clarify the relevant requirements for the confirmation and measurement of environmental accounting information, so as to provide a legal basis for environmental accounting information disclosure by listed companies in the coal industry.

\subsection{Regulate the disclosure of environmental accounting information of listed companies in the coal industry}

Although listed companies in the coal industry in my country have disclosed some environmental accounting information, they have a large selection of information disclosure. They disclose more positive environmental accounting information and less negative environmental accounting information. In order to ensure that information users can obtain comprehensive information, relevant state departments should clearly state the content of environmental accounting information that needs to be compulsorily disclosed by coal companies, and regulate the completeness and detail of environmental accounting information disclosure in the coal industry.

\subsection{Improve the environmental accounting information disclosure and supervision mechanism of listed companies in the coal industry}

The improvement of the environmental accounting information disclosure quality of listed companies in the coal industry requires the efforts of the enterprises themselves on the one hand, and the strengthening of supervision by the regulatory authorities on the other. Listed companies in the coal industry should strengthen their sense of social responsibility, take the initiative to assume responsibility, strengthen the construction of internal supervision mechanisms, and improve the quality of environmental accounting information disclosure. The government and other relevant departments must improve the environmental accounting information disclosure and supervision mechanism, while the supervisory department 
must increase its enforcement, strictly implement the rules and regulations to ensure the quality of environmental accounting information disclosure.

\section{References}

1. Chang jiao Liu.Finance and Accounting Research 1(2018)

2. Shufeng Wang, Lei Shang, Lijia Xi.Friends of accounting(2018)

3. Yamei Guan, Rui Zhao. Accounting communication(2017)

4. Xuguang Zhang, Yanna Xuan, Nan Zhang.Coal economy Research(2019)

5. Yutong Zhou.Shopping Mall modernization(2020) 